\title{
Analysing progress of SDG 6 in India: Past, Present, and Future
}

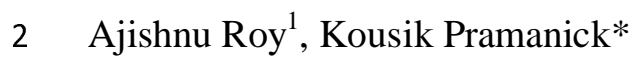

3 Integrative Biology Research Unit (IBRU), Department of Life Sciences, Presidency

4 University, 86/1 College Street Kolkata - 700076

$5 \quad *$ Corresponding author

$6 \quad$ Email: kousik.dbs@ presiuniv.ac.in

\section{Abstract:}

9 Human endeavors to meet social and economic water needs at national scale might cause 10 negative environmental manifestations and water stress from local to global scale. So, 11 appropriation of Sustainable Development Goals requires a comprehensive monitoring and 12 knowledge base of the water resource availability, utilization and access. Hence, scientific 13 research progression has a significant role to facilitate the implementation of sustainable 14 development goals through assessment and policy implementation from global to local scales. 15 India holds a key position among developing economies with a complex interconnected web 16 of a fast-growing population, coupled with biophysical stress, social deprivation and 17 economic inequality related to water and sanitation. This study addresses some of these 18 challenges related to monitoring and implementation of the targets of the United Nations 19 Sustainable Development Goal 6 in India. Acknowledging the contribution of society and 20 economy in sustainability paradigm, here we have chosen 28 indicators (clustered into eleven 21 dimensions) under two major groups, concerning biophysical and social development aspects 22 of water and sanitation. We have shown declining level of per capita biophysical water 23 resource and slow to rapidly developing social indicators related to Sustainable Development

24 Goal 6 in India. From past trends, we have calculated probable scenario of biophysical 25 consumption of India up to 2050, which shows at least 1.3 times increase. This cumulative 
26 assessment framework contributes a tool to prioritize water resource appropriation,

27 management response and policy implementations to national level sustainability of water

28 and sanitation in India. We also advocate the necessity of restraining threats both at source

29 and consumption process levels in order to ensure national water security for both human and

30 biodiversity, keeping in mind the societal and economic development scenario.

31 Keywords: SDG 6; indicators; national water security; water and sanitation; India. 


\section{1. Introduction:}

52 India is going through a time of deterioration of the environment, social deprivation and

53 ineffective economy, combined with the rapidly growing population. This is an example of

54 global scale initiation and progress of 'Anthropocene' (Steffen et al. 2007, 2011). During the

55 1980s, the concept of sustainable development was framed, which is "development that

56 meets the needs of the present without compromising the ability of future generations

57 to meet their own needs" (Brundtland Commission Report, 1987). In 1992 United Nations

58 Conference on Environment and Development (UNCED, Rio de Janeiro Earth Summit),

59 Agenda 21, calls for sustainable development indicators (SDIs) to "provide solid bases for

60 decision-making at all levels and to contribute to a self-regulating sustainability of integrated

61 environment and development system". Emerging from Millennium Development Goals

62 (MDGs), United Nations has set 17 Sustainable Development Goals (SDGs) and 169 targets

63 in 2015. SDGs incorporate three pillars of sustainable development, i.e. environmental

64 (climate action, life below water, life on land etc.), social (zero hunger, no poverty, gender

65 equality, peace and justice and strong institutions etc.) and economic development (reduced

66 inequalities, decent work and economic growth etc.) (Sachs, 2012).

67 There is a distinct trend that was set from the 1970s, especially from 1990s, that led to the

68 contextual understanding and necessity for this study. It can be divided into two phases.

69 In the first phase, the significance of managing water resource sustainably was studied and

70 advocated. Almost all of the works, concerned only with environmental aspect of water

71 resource management. From the 1990s, the significance of the sustainable development of

72 water resources has been increasing steadily. Biswas $(1991,1992)$ emphasised an analytical

73 framework for drivers of the water crisis, socio-environmental considerations along with

74 institutional responses for better management. Long before the present time, Serageldin

75 (1995) had proposed 'water resource management' as a policy tool for sustainable future. 
76 Gleick (1996) recommended that international organizations, national and local governments,

77 with water providers adopt a 'basic water requirement' standard for human needs - 50 litres

78 per person per day and promise access to this independently of an individual's economic,

79 social, or political status. In another work, Gleick (1998) proposed seven 'sustainability

80 criteria' related to "basic water requirement (BWR)" to restructure long-term water planning.

81 These criteria included - basic water requirement for the need and health of both human and

82 ecosystems, water quality monitoring, institutional mechanism for water-related conflict

83 resolution, water planning and decision making etc. Postel (2000) advocated a new water

84 management paradigm which balances both ecological and economic functions of water by

85 increasing water productivity (performing more functions with less water). Vörösmarty et al.

86 (2000) have assessed the vulnerability of global water resource from both climate change and

87 population growth. Jackson et al. (2001) analysed changes in water resources and projected

88 future scenario for the USA. Vörösmarty et al. (2010) presented a global synthesis that jointly

89 considers both human and biodiversity perspective on water security.

90 In the second phase, both economic and societal aspects started to get their due importance in

91 important studies on sustainability analysis. In 2009, Rockström et al. devised a framework to

92 understand if anthropogenic biophysical resource consumption has already exceeded or is

93 going to surpass safe limits - 'planetary boundaries'. This work marked the global onset of

94 biophysical resource consumption monitoring in recent years. Then Steffen et al (2015)

95 modified and improved the framework. One of the main problems in this work is that the

96 indicators used in these works had not been corroborated completely with UN sustainable

97 development goals. Also, the socioeconomic dimension was not comprehensively discussed.

98 This was accomplished by Raworth (2012) through the incorporation of the social deprivation

99 indicators. This acted as a complementary to planetary boundary framework and together

100 formed 'doughnut economy' that touched all three pillars of sustainability - environment, 
101 economy and society. Water and sanitation are strongly related to public health too. Works in 102 this area have also increased (Bartram et al, 2005, Moe and Rheingans, 2006, Montgomery and Elimelech, 2007, Bartram and Cairncross, 2010, Bartram et al. 2014). There has been an important discussion ongoing that specifically signifies water and sustainable development is perceived from this water-perspective (Bogardi et al. 2012, Madrid et al. 2013, Bhaduri et al. 2016, Ait-Kadi, 2016).

107 There has been some work on the appropriation of water resources and its management in India (Kumar et al. 2005, Shah and Koppen, 2006, Mall et al, 2006, Mujumdar, 2008). An important lacuna is that none of these incorporate socioeconomic dimensions in sustainability analysis of water resource. All of these studies logically imply the need for a national study on the sustainable development of water and sanitation that includes environment, society and economy together. That's why this study was performed.

There is no national level study present focusing on both biophysical and socioeconomic aspects of SDG 6 i.e. sustainable development of water and sanitation. In this work, we have tried to find answers to the following: (1) How can we downscale SDG 6 indicators to a national scale more accurately? (2) How can we understand changes in dimensions of SDG 6 with time in order to contextualize their present values? (3) How can we use the past trends in per capita biophysical consumptions under SDG 6 to project probable future biophysical resource consumption at a national scale? This analysis measures the national performance of India on SDG 6 through11dimensions, 28 indicators, segregated into 2 groups, biophysical and social development indicators, provides important findings of the relationship between biophysical resource use and well-being for India. Our work has been explained herein few steps. We first present our methodology, then results of our study on India; project probable

124 future scenario of biophysical consumption for India; discuss limitations and scopes of this 
125 study, the applicability of SDG 6 as a tool in policymaking and necessities for future 126 improvements in research.

127

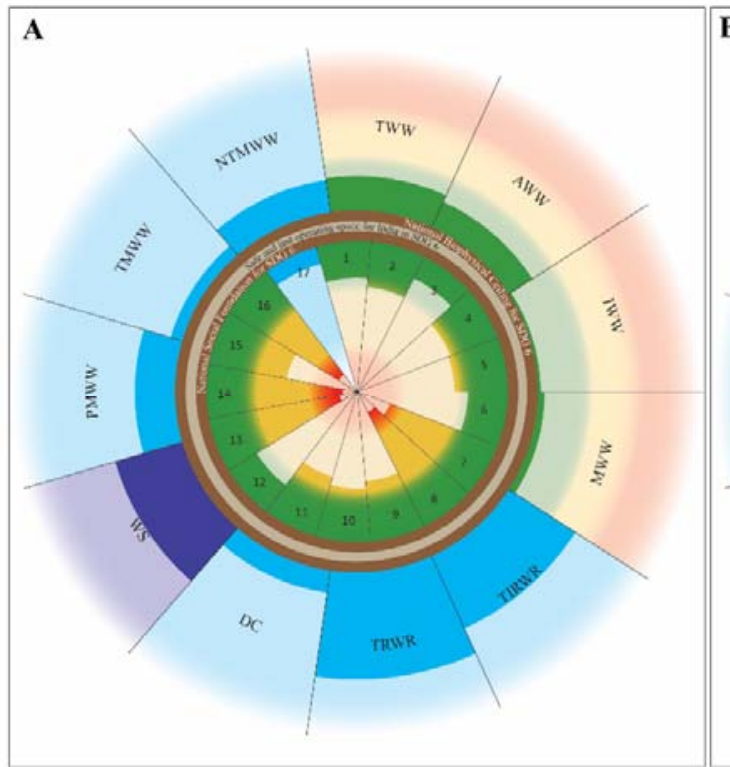

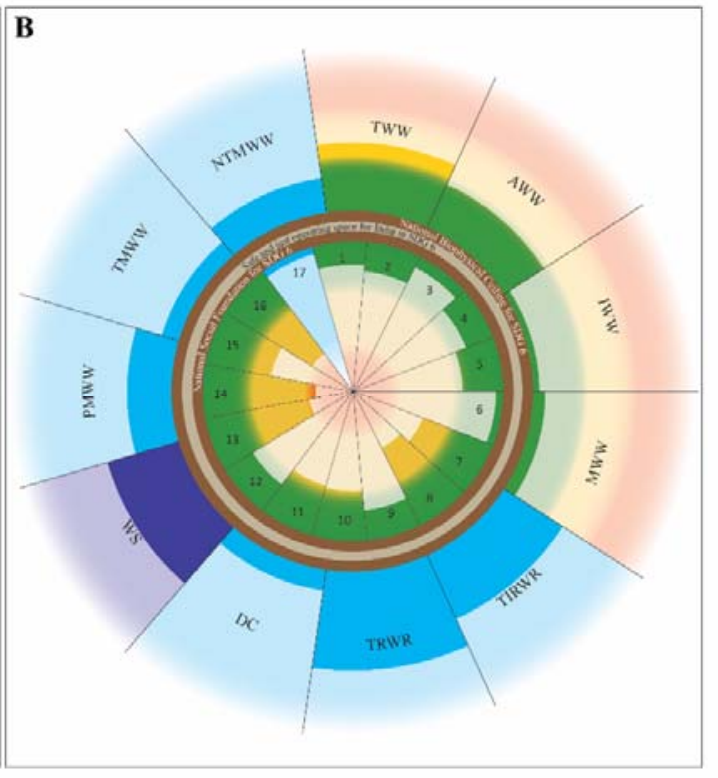

135 Fig. 1. Changes in biophysical and social development indicators related to sustainable development goal 6 in India.

137 A and B represent the status of sustainable development of India in 2000 and 2015 138 respectively. Eleven indicators of biophysical stress established over biophysical ceiling 139 (outer chocolate ring) outwardly projected and seventeen indicators of social development 140 established under social foundation (inner chocolate ring) inwardly projected for India. 
141 Biophysical indicators are - total water withdrawal (TWW), agricultural water withdrawal

142 (AWW), industrial water withdrawal (IWW), municipal water withdrawal (MWW), total

143 internal renewable water resource (TIRWR), total renewable water resource (TRWR), dam

144 capacity (DC), water stress (WS), produced amount of municipal wastewater (PMWW),

145 treated municipal wastewater (TMWW) and non-treated municipal wastewater (NTMWW).

146 Indicators of social development are - (1) Improved sanitation facilities, (2) Improved

147 sanitation facilities in rural areas, (3) Improved sanitation facilities in urban areas, (4)

148 Improved water source, (5) Improved water source in rural areas, (6) Improved water source

149 in urban areas, (7) People practicing open defecation, (8) Rural people practicing open

150 defecation, (9) Urban people practicing open defecation, (10) People using at least basic

151 drinking water services, (11) Rural people using at least basic drinking water services, (12)

152 Urban people using at least basic drinking water services, (13) People using at least basic

153 sanitation services, (14) Rural people using at least basic sanitation services, (15) Urban

154 people using at least basic sanitation services, (16) Rural people using safely managed

155 drinking water services, (17) Water use efficiency in agriculture.

156 Green indicates safe operating space for biophysical indicators and thresholds for indicators

157 of social development. Yellow indicates the zone of increasing impact for biophysical

158 indicators and zone of increasing deprivation for indicators of social development. Red

159 indicates the zone of high risk of serious impact for biophysical indicators and zone of high

160 level of deprivation for indicators of social development. Light blue represents indicators

161 without any boundary or thresholds $\left(\right.$ Unit $-\mathrm{m}^{3}$ ). Violet represents water stress (Unit - \%).

162 The area between the chocolate rings is the safe and just operating space for the sustainable

163 development of water and sanitation in India.

164 2.1. Biophysical Indicators: 
165 We analyzed 11 indicators under 4 dimensions that indicate biophysical aspects of SDG 6

166 (Table 1). These 4 dimensions of biophysical indicators are - water withdrawal (4 indicators),

167 water availability (3 indicators), wastewater (3 indicators) and water stress, WS (1 indicator).

168 We calculated every biophysical indicator on per capita basis by dividing total values with

169 population data of India, available from FAOSTAT database (except - water stress,

170 expressed in percentage, \%). We tried to include indicators for water pollution, water

171 scarcity, the condition of water-related ecosystems, water footprint etc. Either no

172 unanimously accepted indicator is available or there is no established database with annual

173 data for the significantly longer duration. So, we could not include any indicator representing

174 these dimensions.

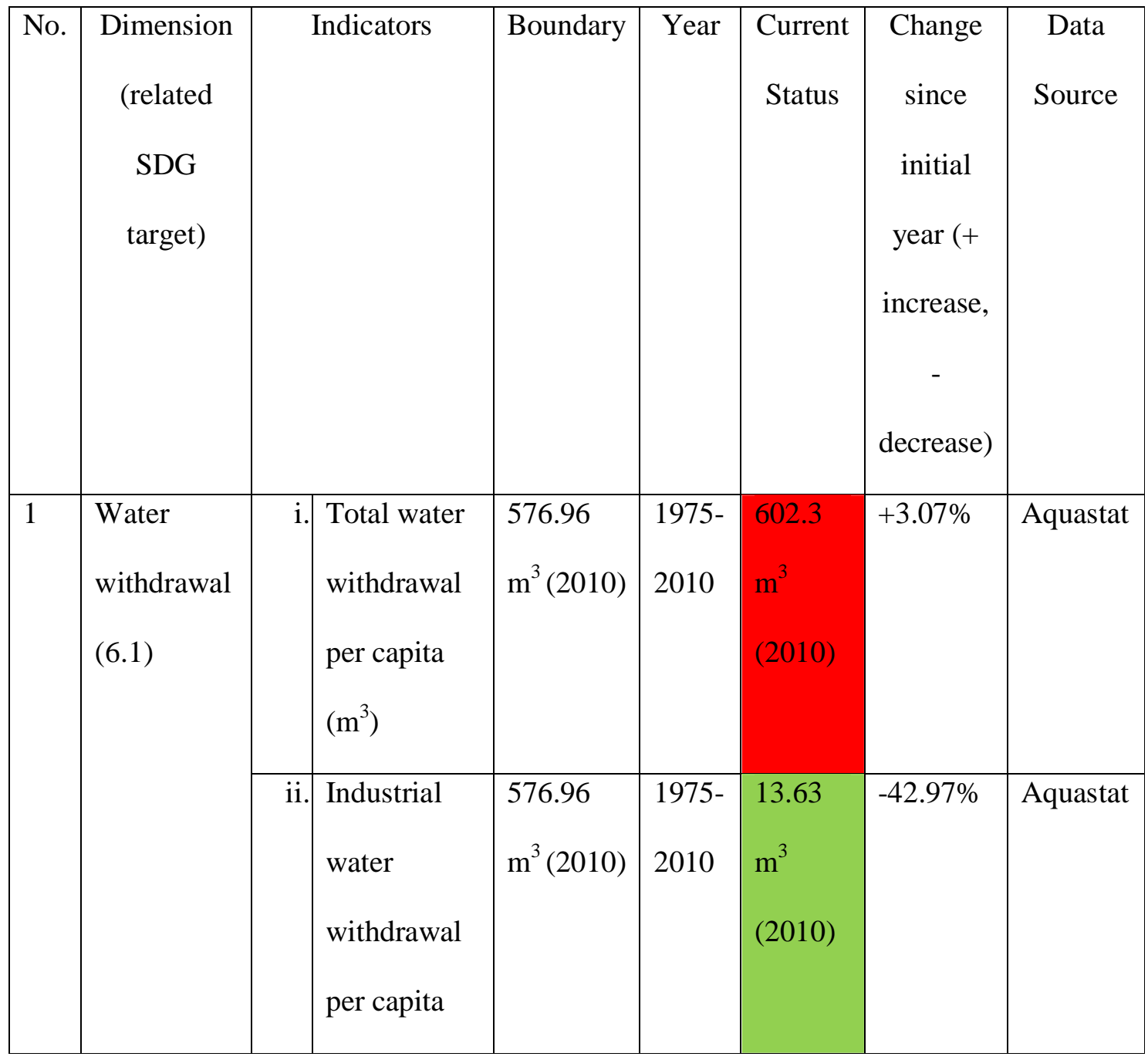




\begin{tabular}{|c|c|c|c|c|c|c|c|c|}
\hline & & & $\left(\mathrm{m}^{3}\right)$ & & & & & \\
\hline & & iii. & $\begin{array}{l}\text { Agricultural } \\
\text { water } \\
\text { withdrawal } \\
\text { per capita } \\
\left(\mathrm{m}^{3}\right)\end{array}$ & $\begin{array}{l}576.96 \\
\mathrm{~m}^{3}(2010)\end{array}$ & $\begin{array}{l}1975- \\
2010\end{array}$ & $\begin{array}{l}551.62 \\
\mathrm{~m}^{3} \\
(2010)\end{array}$ & $-0.76 \%$ & Aquastat \\
\hline & & iv. & $\begin{array}{l}\text { Municipal } \\
\text { water } \\
\text { withdrawal } \\
\text { per capita } \\
\left(\mathrm{m}^{3}\right)\end{array}$ & $\begin{array}{l}576.96 \\
\mathrm{~m}^{3}(2010)\end{array}$ & $\begin{array}{l}1975- \\
2010\end{array}$ & $\begin{array}{l}44.9 \mathrm{~m}^{3} \\
(2010)\end{array}$ & $+60.06 \%$ & Aquastat \\
\hline 2 & $\begin{array}{l}\text { Water } \\
\text { availability } \\
(6.1)\end{array}$ & $\mathrm{v}$. & $\begin{array}{l}\text { Total } \\
\text { internal } \\
\text { renewable } \\
\text { water } \\
\text { resources } \\
\text { per capita } \\
\left(\mathrm{m}^{3}\right)\end{array}$ & $\begin{array}{l}\text { Boundary } \\
\text { not } \\
\text { available. }\end{array}$ & $\begin{array}{l}1962- \\
2014\end{array}$ & $\begin{array}{l}1103 \\
\mathrm{~m}^{3} \\
(2014)\end{array}$ & $-64.29 \%$ & Aquastat \\
\hline & & vi. & $\begin{array}{l}\text { Total } \\
\text { renewable } \\
\text { water } \\
\text { resources } \\
\text { per capita } \\
\left(\mathrm{m}^{3}\right)\end{array}$ & $\begin{array}{l}\text { Boundary } \\
\text { not } \\
\text { available. }\end{array}$ & $\begin{array}{l}1962- \\
2014\end{array}$ & $\begin{array}{l}1458 \\
\mathrm{~m}^{3} \\
(2014)\end{array}$ & $-64.29 \%$ & Aquastat \\
\hline & & vii. & Dam & Boundary & 1960- & 189.9 & $+38.12 \%$ & Aquastat \\
\hline
\end{tabular}




\begin{tabular}{|c|c|c|c|c|c|c|c|c|}
\hline & & & $\begin{array}{l}\text { capacity per } \\
\text { capita }\left(\mathrm{m}^{3}\right)\end{array}$ & $\begin{array}{l}\text { not } \\
\text { available. }\end{array}$ & 2005 & $\begin{array}{l}\mathrm{m}^{3} \\
(2005)\end{array}$ & & \\
\hline \multirow[t]{3}{*}{3} & \multirow[t]{3}{*}{$\begin{array}{l}\text { Wastewater } \\
(6.3 .1)\end{array}$} & viii. & $\begin{array}{l}\text { Produced } \\
\text { municipal } \\
\text { wastewater } \\
\text { per capita } \\
\left(\mathrm{m}^{3}\right)\end{array}$ & $\begin{array}{l}\text { Boundary } \\
\text { not } \\
\text { available. }\end{array}$ & $\begin{array}{l}1979- \\
2011\end{array}$ & $\begin{array}{l}12.23 \% \\
(2011)\end{array}$ & $+64.68 \%$ & Aquastat \\
\hline & & ix. & $\begin{array}{l}\text { Treated } \\
\text { municipal } \\
\text { wastewater } \\
\text { per capita } \\
\left(\mathrm{m}^{3}\right)\end{array}$ & $\begin{array}{l}\text { Boundary } \\
\text { not } \\
\text { available. }\end{array}$ & $\begin{array}{l}1979- \\
2011\end{array}$ & $\begin{array}{l}3.49 \% \\
(2011)\end{array}$ & $+58.86 \%$ & Aquastat \\
\hline & & x. & $\begin{array}{l}\text { Not treated } \\
\text { municipal } \\
\text { wastewater } \\
\text { per capita } \\
\left(\mathrm{m}^{3}\right)\end{array}$ & $\begin{array}{l}\text { Boundary } \\
\text { not } \\
\text { available. }\end{array}$ & $\begin{array}{l}1979- \\
2011\end{array}$ & $\begin{array}{l}8.73 \% \\
(2011)\end{array}$ & $+67.58 \%$ & Aquastat \\
\hline 4 & $\begin{array}{l}\text { Water } \\
\text { Stress } \\
(6.4 .2)\end{array}$ & xi. & $\begin{array}{l}\text { Water stress } \\
(\%)\end{array}$ & $\begin{array}{l}\text { Boundary } \\
\text { not } \\
\text { available. }\end{array}$ & $\begin{array}{l}1979- \\
2011\end{array}$ & $\begin{array}{l}44.53 \% \\
(2011)\end{array}$ & $+18.4 \%$ & Aquastat \\
\hline
\end{tabular}

176 Table 1. Biophysical indicators related to SDG 6 for India

177 Values for indicators that are within per capita global average freshwater use PB are shown in

178 green. Those have crossed the boundary, are shown in red.

\subsection{Social development Indicators:}


180 We analysed 17 indicatorsunder7 dimensions that indicate social development aspects related

181 to SDG 6 (Table 2). These 7 dimensions of social development indicators are - open 182 defecation (3 indicators), basic drinking water (3 indicators), basic sanitation services (3 183 indicators), safely managed drinking water services (1 indicator), improved sanitation 184 services (3 indicators), improved water source (3 indicators) and water use efficiency, WUE 185 (1 indicator). We have also set a desirable threshold for social development indicators to get a 186 better understanding of gaps between current status and desired status that can be reasonably accepted as the well-developed situation of SDG 6 for India. These are - less than 10\% people for open defecation and $90 \%$ or more people for rest of 5 dimensions (excluding water use efficiency, WUE). We have also calculated the approximate time when desired thresholds were or will be met for social development indicators (excluding water use efficiency, WUE) using linear interpolation at business-as-usual, BAU scenario. The details of each indicator, along with duration, current status, change, threshold/boundary meeting time etc. are provided in Table 1 (biophysical indicators of SDG 6) and Table 2 (social development indicators of SDG 6).

\begin{tabular}{|c|c|c|c|c|c|c|c|c|c|}
\hline No & $\begin{array}{l}\text { Dimen } \\
\text { sions }\end{array}$ & & dicators & $\begin{array}{c}\text { Threshol } \\
\text { d }\end{array}$ & Year & $\begin{array}{c}\text { Curre } \\
\text { nt } \\
\text { Status }\end{array}$ & $\begin{array}{l}\text { Change } \\
\text { since } \\
\text { initial } \\
\text { year (+ } \\
\text { increase } \\
\text {, - } \\
\text { decreas } \\
\text { e) }\end{array}$ & $\begin{array}{c}\text { Data } \\
\text { Source }\end{array}$ & $\begin{array}{c}\text { Threshol } \\
\qquad \mathrm{d} \\
\text { meeting } \\
\text { time } \\
\text { (BAU) }\end{array}$ \\
\hline 1 & $\begin{array}{l}\text { Open } \\
\text { defeca }\end{array}$ & i. & $\begin{array}{l}\text { People } \\
\text { practicing }\end{array}$ & $\begin{array}{l}\text { Less } \\
\text { than }\end{array}$ & $\begin{array}{l}2000 \\
-\end{array}$ & $\begin{array}{l}39.83 \\
\%\end{array}$ & $\begin{array}{c}- \\
26.14 \%\end{array}$ & $\begin{array}{l}\text { World } \\
\text { bank }\end{array}$ & $\begin{array}{l}2030- \\
2035\end{array}$ \\
\hline
\end{tabular}




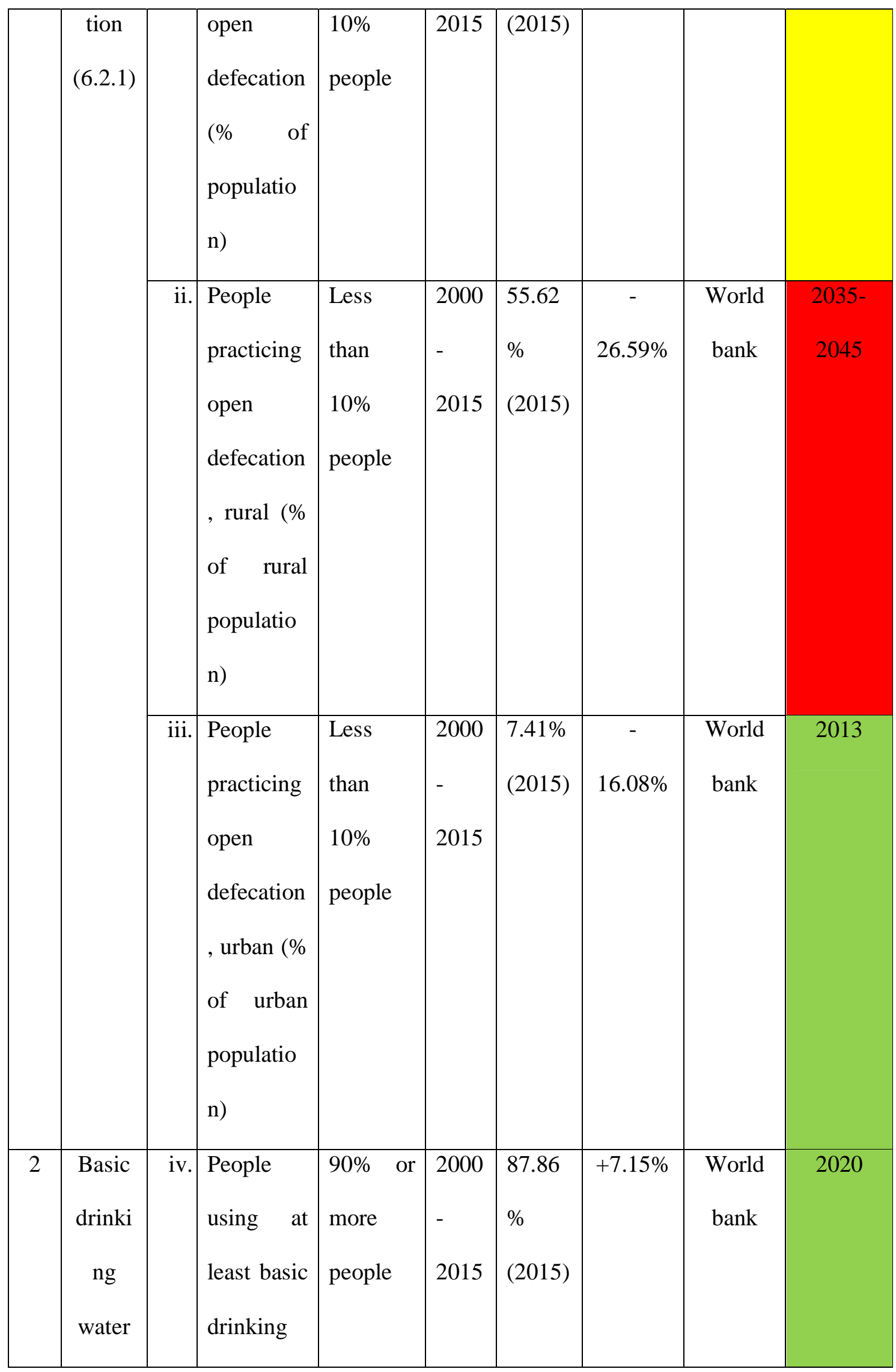




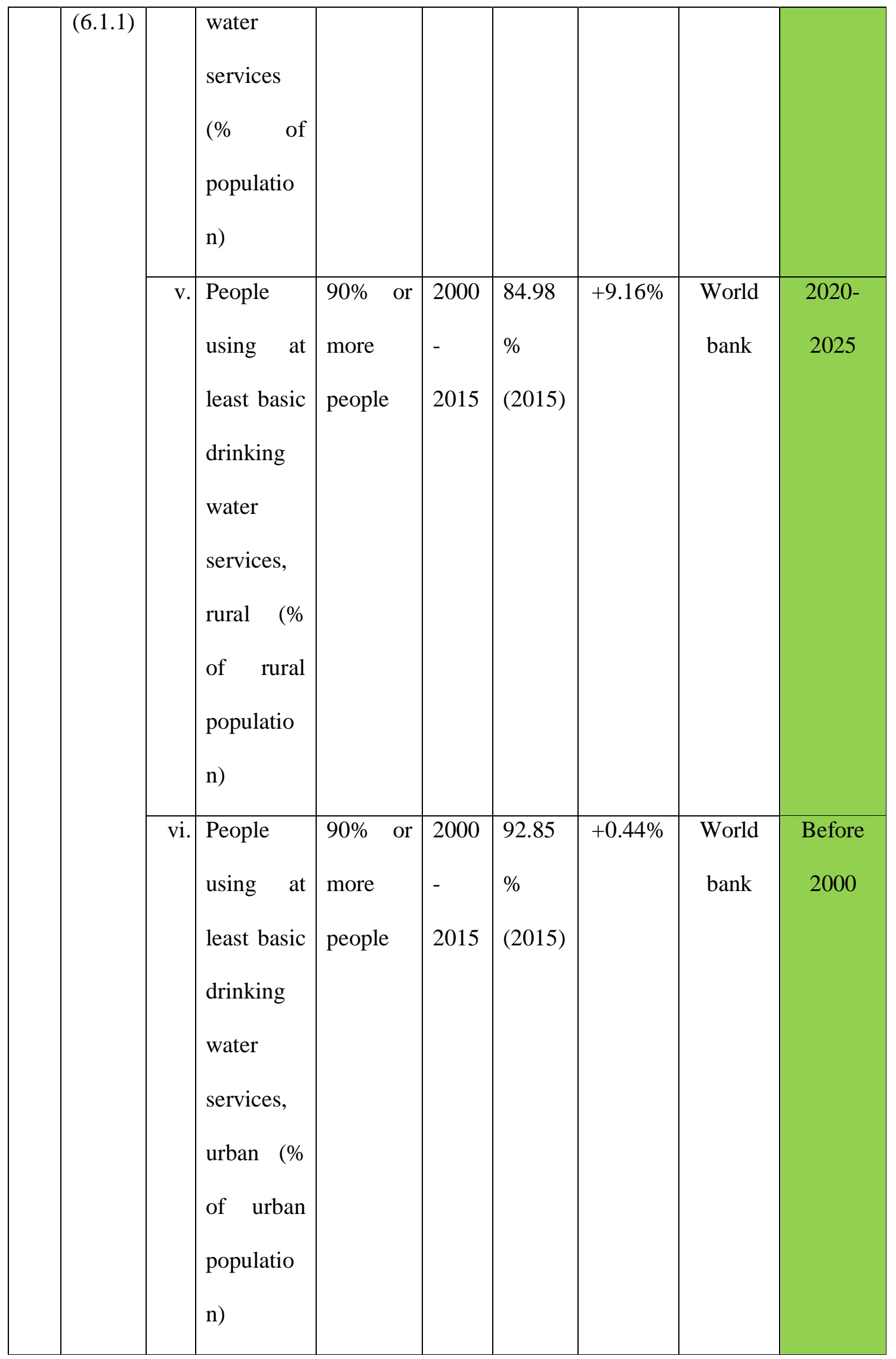




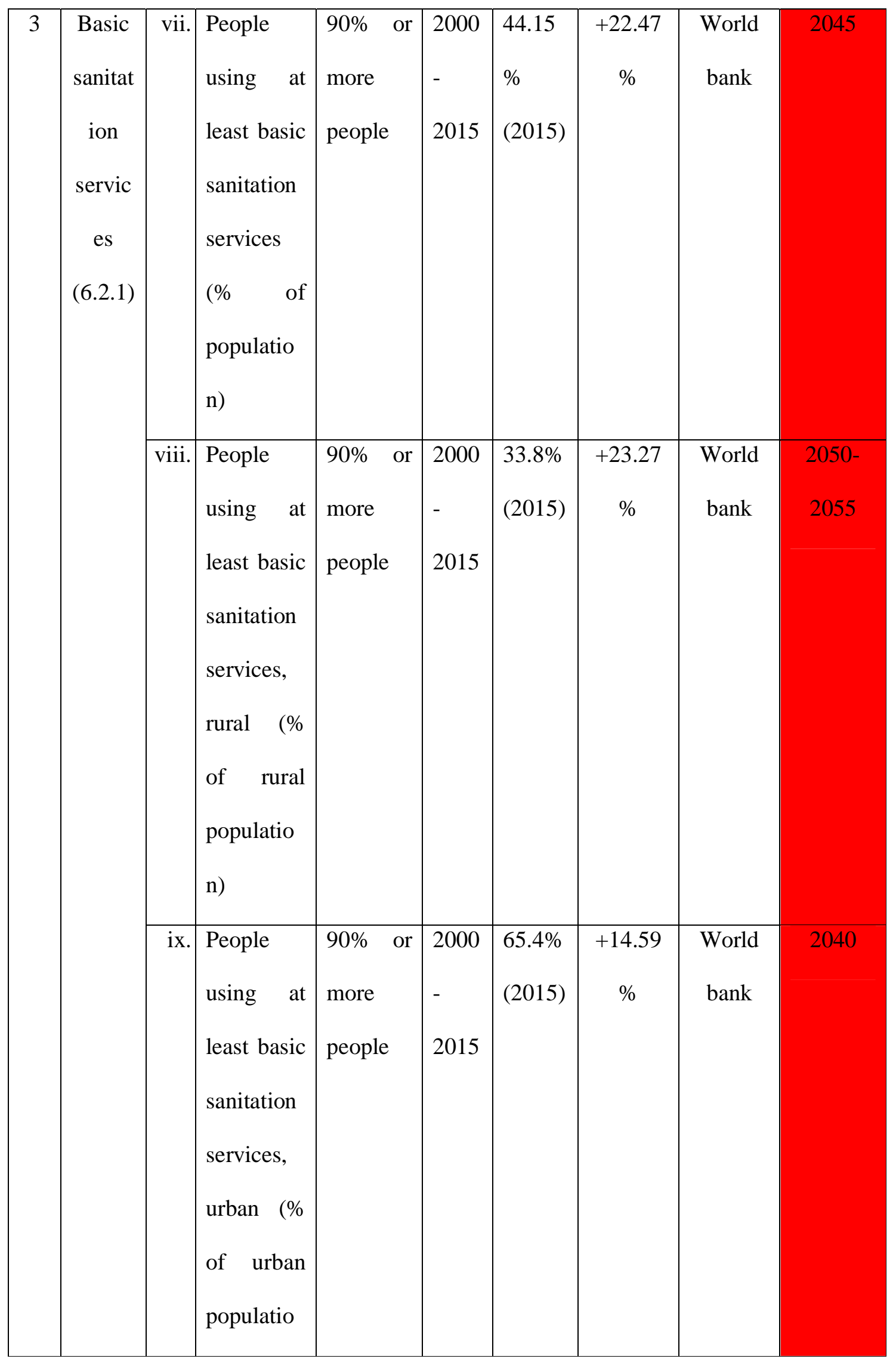




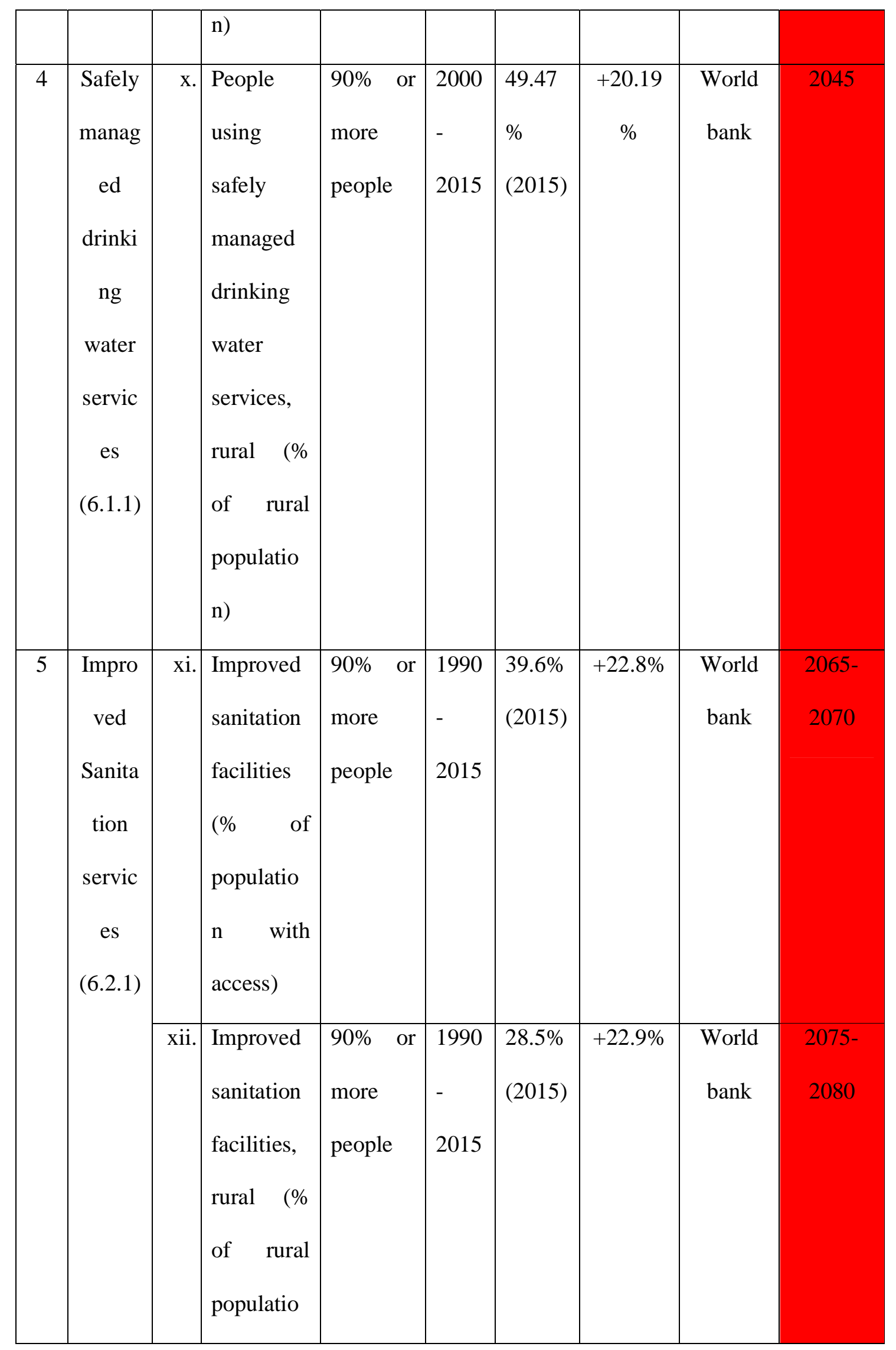




\begin{tabular}{|c|c|c|c|c|c|c|c|c|c|}
\hline & & & $\begin{array}{l}\text { n with } \\
\text { access) }\end{array}$ & & & & & & \\
\hline & & xiii. & $\begin{array}{l}\text { Improved } \\
\text { sanitation } \\
\text { facilities, } \\
\text { urban (\% } \\
\text { of urban } \\
\text { populatio } \\
\text { n with } \\
\text { access) }\end{array}$ & $\begin{array}{l}90 \% \text { or } \\
\text { more } \\
\text { people }\end{array}$ & $\begin{array}{l}1990 \\
- \\
2015\end{array}$ & $\begin{array}{l}62.6 \% \\
(2015)\end{array}$ & $+13.3 \%$ & $\begin{array}{l}\text { World } \\
\text { bank }\end{array}$ & $\begin{array}{l}2060- \\
2065\end{array}$ \\
\hline 6 & $\begin{array}{c}\text { Impro } \\
\text { ved } \\
\text { water } \\
\text { source } \\
\text { (6.1.1) }\end{array}$ & xiv. & $\begin{array}{l}\text { Improved } \\
\text { water } \\
\text { source (\% } \\
\text { of } \\
\text { populatio } \\
\text { with } \\
\text { access) }\end{array}$ & $\begin{array}{l}90 \% \text { or } \\
\text { more } \\
\text { people }\end{array}$ & $\begin{array}{l}1990 \\
- \\
2015\end{array}$ & $\begin{array}{l}94.1 \% \\
(2015)\end{array}$ & $+23.6 \%$ & $\begin{array}{l}\text { World } \\
\text { bank }\end{array}$ & 2010 \\
\hline & & XV. & $\begin{array}{l}\text { Improved } \\
\text { water } \\
\text { source, } \\
\text { rural (\% } \\
\text { of rural } \\
\text { populatio } \\
\text { n with } \\
\text { access) }\end{array}$ & $\begin{array}{l}90 \% \text { or } \\
\text { more } \\
\text { people }\end{array}$ & $\begin{array}{l}1990 \\
- \\
2015\end{array}$ & $\begin{array}{l}92.6 \% \\
(2015)\end{array}$ & $+28.4 \%$ & $\begin{array}{l}\text { World } \\
\text { bank }\end{array}$ & 2012 \\
\hline
\end{tabular}




\begin{tabular}{|c|c|c|c|c|c|c|c|c|c|}
\hline & & xvi. & $\begin{array}{l}\text { Improved } \\
\text { water } \\
\text { source, } \\
\text { urban (\% } \\
\text { of urban } \\
\text { populatio } \\
\text { n with } \\
\text { access) }\end{array}$ & $\begin{array}{l}90 \% \text { or } \\
\text { more } \\
\text { people }\end{array}$ & $\begin{array}{l}1990 \\
- \\
2015\end{array}$ & $\begin{array}{l}97.1 \% \\
(2015)\end{array}$ & $+8.2 \%$ & $\begin{array}{l}\text { World } \\
\text { bank }\end{array}$ & 1994 \\
\hline 7 & $\begin{array}{c}\text { Water } \\
\text { use } \\
\text { efficie } \\
\text { ncy } \\
\text { (6.4.1) }\end{array}$ & Xvii. & $\begin{array}{l}\text { Water use } \\
\text { efficiency, } \\
\text { agricultur } \\
\text { e (water } \\
\text { withdrawa } \\
\text { l, } \mathrm{m}^{3} / \\
\text { GDP, } \\
\text { current } \\
\text { US\$) }\end{array}$ & $\begin{array}{l}\text { Threshol } \\
\text { d not } \\
\text { available }\end{array}$ & $\begin{array}{l}1975 \\
- \\
2010\end{array}$ & $\begin{array}{l}2.2 \\
\mathrm{~m}^{3} / \\
\text { GDP, } \\
\text { curren } \\
\text { t US\$ } \\
\text { (2010) }\end{array}$ & $\begin{array}{c}- \\
76.16 \%\end{array}$ & $\begin{array}{l}\text { Aquasta } \\
\text { t, World } \\
\text { bank }\end{array}$ & \\
\hline
\end{tabular}

195 Table 2. Social development indicators related to SDG 6 for India

196 Indicators that are going to meet threshold within UN SGD target time (2030) are shown in

197 green. Those going meet few years after that time are shown in yellow and indicators, which

198 are going to meet desired threshold many years after 2030 are shown in red.

\subsection{Planetary boundary of freshwater use:}

200 According to Rockström et al. (2009), the planetary boundary of freshwater use is the 201 maximum withdrawal of $4000 \mathrm{~km}^{3} \mathrm{y}^{-1}$ blue water from rivers, lakes, reservoirs, and 
202 renewable groundwater stores. We divided it with world population (from World Bank) to get

203 per capita global scale boundary of $576.96 \mathrm{~km}^{3} \mathrm{y}^{-1}(2010)$.

\subsection{Future scenario:}

205 As we have calculated most of the biophysical indicators on per capita basis (except - water 206 stress, in \%), it is possible to project probable future scenario of total consumption. We 207 collected future population projection (2015-2050) data (median range prediction value of $20850 \%$ ) of India from UN DESA (2017 Revision) and then multiplied it with 10 per capita consumption indicators of SDG 6. We have calculated three projection series for each of 10 indicators of SDG 6, (i) with the lowest value that has happened in past year, (ii) highest value that has happened in past year and (iii) business-as-usual, BAU scenario with latest available data.

\section{3. Results and Interpretation:}

\section{3.1. Biophysical Indicators:}

215 Among the 11 indicators concerning biophysical aspects of SDG 6, 4 have decreased and 7 have increased over time (Table 1).

Both total internal renewable water resource and total renewable water resource have significantly decreased $(64.29 \%)$ which is expected, as the population is growing but the available amount of renewable water resource is not. In future, with more population growth, per capita available renewable water resource is likely to decrease further. This problem can be tackled in 2 ways, (1) control of population growth in India and (2) increasing water productivity, i.e. perform more functions with less amount of water, in another word, becoming more water-efficient. Industrial water withdrawal has decreased significantly (42.97\%) that might prove to be good, especially for India. More water will be available for agriculture (India has an agriculture-based economy) and domestic consumption (India is 
227 withdrawal has decreased very less $(0.76 \%)$ during the time (1975-2010), yet the population

228 has increased much more i.e. total amount of agricultural water withdrawal have increased. It 229 means water productivity in agriculture has not increased significantly in India. Therefore, 230 increasing water productivity in agriculture i.e. growing more agricultural products using less 231 water (direct or indirect use) should be one of the future concerns.

232 Total water withdrawal per capita have increased (3.07\%). As population will increase in 233 future, at this rate of increasing water withdrawal water scarcity will be more severe unless 234 proper mitigation strategies are adopted. Municipal water withdrawal has also increased 235 significantly $(60.06 \%)$ which is probably due to increasing number of urban population. 236 Thus, in 2050, if 50\% of Indian population become urban dwelling (world urban prospects, 237 UN-DESA, 2014 revision), this is likely to be continued, might even at higher rate. As a 238 result, in future, it might not be possible to provide sufficient water for drinking and 239 sanitation equitably to all urban people. Bringing down indiscriminate use of water in 240 municipality areas is one of the probable solutions. If situation arise to more severe stage, 241 water tax might be considered for implementation, especially for high-income urban 242 localities. It is also a good time to start thinking about possible sources of freshwater in and 243 around urban areas for supply to increased urban population in future. Continuous monitoring 244 to check misuse of municipality provided water is needed. For domestic use in 2050, India 245 would require 111 billion $\mathrm{m}^{3}$ water. Top 6 domestic water states (more than 8 billion $\mathrm{m}^{3}$ 246 water) would be - Uttar Pradesh, Bihar, Maharashtra, West Bengal, Madhya Pradesh and 247 Andhra Pradesh (IndiaStat 2018). (Supplementary Fig. 1). Total annual water requirement is 248 increasing steadily in India. In 2050, water requirement is going to be almost three times the 249 requirement of 1990 . Water demand for power generation is going to increase more in 2025 250 and 2050 (IndiaStat 2018) (Supplementary Fig. 2). Dam capacity per capita have increased 251 (38.12\%). It means, as population is increasing, more numerous and larger capacity dams are 
252 being prepared or going to be needed to prepare in future to maintain this per capita rate. In

253 one hand, more hydroelectric power is necessary for growing Indian population, in another

254 hand, adverse effects of present and future construction of dams on aquatic life, especially

255 riverine biota should be kept in mind (LeRoy Poff et al. 2007, Vörösmarty et al. 2010). Not

256 only aquatic biodiversity is major source of livelihood of millions of people around river

257 basins, but also protection and conservation of aquatic biodiversity is also priority. Produced

258 and treated municipal wastewater has increased significantly $(64.68 \%$ and $58.86 \%$,

259 respectively). But not treated municipal wastewater has increased more (67.58\%). It means

260 more amount of wastewater is remaining untreated than treated portion which brings bad

261 effects of wastewater in environment, soil, biodiversity etc. along with it. More wastewater

262 treatment plants or centres accompanied with more recycle and reuse of water are necessary

263 in future. Water stress has also increased (18.4\%). Current water stress level in India

$264(44.53 \%)$ is almost 4 times more than average global level of water stress $(12.82 \%)$. This

265 indicates water stress is steadily increasing and would become more complex problem in

266 future with growing number of Indian population. Changes of biophysical consumption

267 indicators are depicted in Fig 2. 

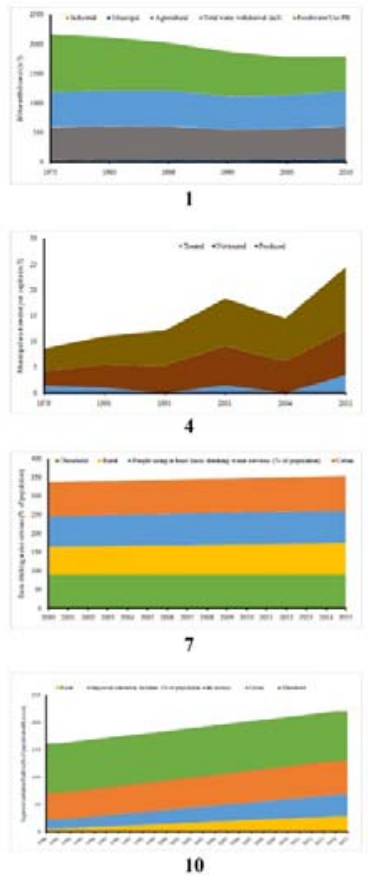
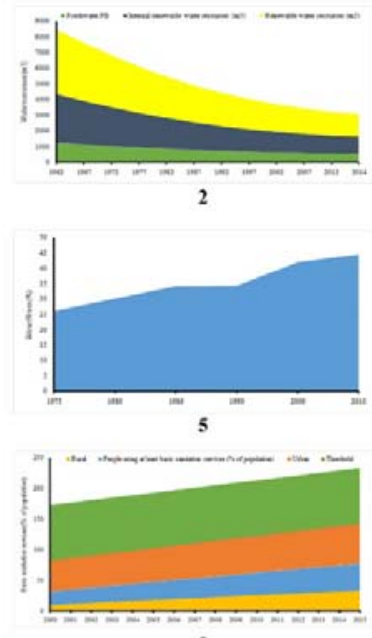

8

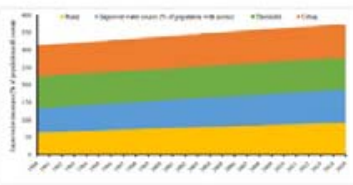

11
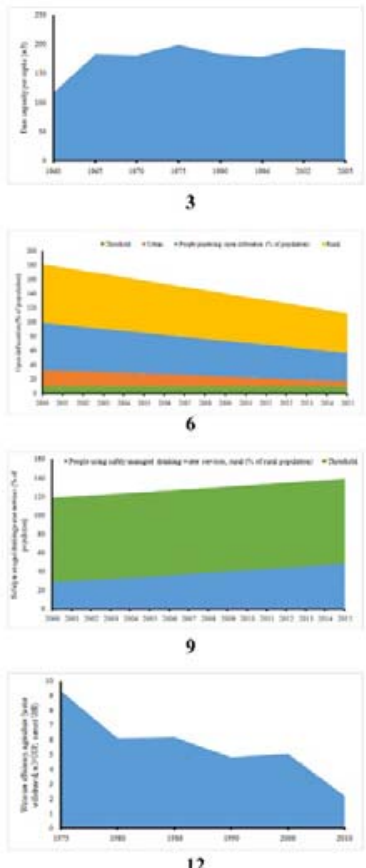

12

270 Fig. 2. Changes in per capita biophysical indicators (1-5) and indicators of social

271 development (6-12) related to sustainable development goal 6 in India with time.

272 Green indicates global per capita boundaries for biophysical indicators and thresholds for 273 indicators of social development.

274 Biophysical indicators are - (1) water withdrawal $\left(\mathrm{m}^{3}\right),(2)$ water resources $\left(\mathrm{m}^{3}\right)$, (3) dam 275 capacity $\left(\mathrm{m}^{3}\right),(4)$ municipal wastewater $\left(\left(\mathrm{m}^{3}\right)\right.$ and $(5)$ water stress $(\%)$. Indicators for social 276 development are - (6) open defecation (\%), (7) basic drinking water services (\%), (8) basic 277 sanitation services (\%), (9) safely managed drinking water services (\%), (10) improved 278 sanitation facilities (\%) (11) improved water source (\%) and (12) water use efficiency in 279 agriculture $\left(\mathrm{m}^{3} / \mathrm{GDP}\right.$, current US\$).

\subsection{Social development Indicators:}

281 Of the 17 indicators of social development aspects of SDG 6, 4 have decreased and 13 have increased over time (Table 2). 
283 Open defecation rate in India has decreased in all 3 cases, overall (26.14\%), rural (26.59\%)

284 and urban $(16.08 \%)$. Urban open defecation rate has already met with the desired threshold

285 (10\% or less) in 2013. Although the success, it should be also kept in mind that with

286 increasing number of urban populous in coming decades, maintaining this rate might prove to

287 be tougher. So, necessary actions should be made parallelly for implementation in need be in

288 future. Remaining two will not be able to meet SDG criteria at this rate within 2030 (2030-35

289 and 2035-40, respectively). It means open defecation in rural areas needs to decrease more.

290 There are 2 possible ways for that, (1) more public and household toilets are to be constructed

291 in rural areas and (2) spreading awareness about adverse effects of open defecation on

292 environment and health in rural areas. On average, 35.09\% villages in India are open-

293 defecation free as of 2017. Four are lowest (0\%) among them (Dadra and Nagar Haveli,

294 Daman and Diu, Goa and Puducherry) and five have highest (100\%) achievement (Haryana,

295 Himachal Pradesh, Kerala, Sikkim and Uttarakhand) (Supplementary Fig. 3) (IndiaStat

296 2018). Water use efficiency in agriculture has also decreased significantly (76.16\%) which is

297 good, i.e. less amount of water is being withdrawn for the same amount of GDP (in current

298 US\$, 2010).

299 Basic drinking water services has also increased (overall, 7.15\%; rural, 9.16\% and urban, 300 0.44\%). Basic drinking water in urban areas has already met with a desirable threshold (90\% 301 or more) before 2000. Remaining two will also be able to meet SDG criteria at this rate 302 within 2030 (2020 and 2020-25, respectively). Basic sanitation services have increased in 303 India (overall, 22.47\%; rural, 23.27\% and urban, 14.59\%). But, none of the 3 will be able to 304 meet desired SDG criteria within 2030 (2045, 2050-2055 and 2040 respectively). Immediate 305 steps are needed to improve awareness and basic sanitation system. Safely managed drinking 306 water services in rural Indian population has also increased over time $(20.19 \%)$. But it will 307 also not be able to meet desired SDG threshold within 2030 (2045). Improved sanitation 
308 facilities have also increased over time (overall, 22.8\%; rural, 22.9\% and urban, 13.3\%). As

none of the 3 indicators will be able to meet desired SDG criteria within 2030 (2065-2070,

2075-2080 and 2060-2065 respectively), improvement of sanitation services requires serious

attention in India (both rural and urban area). Improved water source has increased over time

312 (overall, 23.6\%; rural, 28.4\% and urban, 8.2\%). All of these 3 indicators have already meet

desired SDG criteria (2010, 2012 and 1994 respectively). To sum up, in India, among 16

indicators with desirable thresholds, 7 have either already met or going to meet SDG criteria

within 2030, 1 indicator will reach the target just after 2030, and remaining 8, at current rate,

will be able to meet in distant future (2040-2080), requiring immediate attention. Changes in

social development indicators over time are seen in Fig 2.

\subsection{Planetary boundary of freshwater use at the national scale:}

319 From this analysis, we can see that Indian per capita total water withdrawal (2010) has 320 already crossed global average freshwater use PB $\left(576.96 \mathrm{~m}^{3}, 2010\right)$ (Fig. 1). This means that 321 with growing population it would be tougher for to achieve UN SDG 6 targets remaining under safe biophysical limits of water resource use.

\subsection{Future of SDG 6:}

324 Fig 3 shows total amount of probable biophysical consumption up to 2050 in 9 graphs. In 325 2050, if lowest per capita rate can be maintained, total water withdrawal would increase $32618.98 \%$, at a business-as-usual rate, it would increase $25.8 \%$ and at highest per capita rate, it 327 would increase $26.57 \%$. It means even with grown population level of 2050 , it is possible to lower the rate of total water withdrawal $6.8-7.5 \%$ and which is a significant amount. In agricultural water withdrawal in 2050, at lowest per capita rate, it would increase $20.98 \%$, at a business-as-usual rate, it would increase $25.8 \%$ and at highest per capita rate, it would increase $29.1 \%$. Agricultural water withdrawal might to be 1.4 times more in 2050 than 2010 . 
333 which is a very positive scenario. But at a business-as-usual rate, industrial water withdrawal

334 would increase $25.8 \%$ and at highest per capita rate, it would increase $57.7 \%$ in 2050 . For

335 municipal water withdrawal, at lowest per capita rate, it would decrease $46.18 \%$ in 2050

336 which is a positive scenario, whereas for business-as-usual (this is also highest per capita)

337 rate, it would increase $25.8 \%$. For produced municipal wastewater, in 2050 , it is possible able

338 to reduce it to $53.02 \%$ maintaining lowest per capita rate. Otherwise, at business-as-usual

339 (highest per capita) rate, it would increase $24.82 \%$. Municipal wastewater production might

340 be 1.3 times more in 2050 than 2011 . For treated municipal wastewater, it would decrease to

$34160.71 \%$ maintaining lowest per capita rate. But at business-as-usual (highest per capita) rate

342 of wastewater treatment, amount of treated municipal wastewater would increase $24.82 \%$

343 which is also positive scenario. For non-treated municipal wastewater, it is possible to

344 decrease it to $56.83 \%$ maintaining lowest per capita rate in 2050. On another hand, at

345 business-as-usual (highest per capita) rate, it would increase $24.82 \%$ which paints a bleak

346 future of India. This non-treated municipal wastewater might be 1.33 times more in 2050 than

347 2011. Both total renewable water resource and total internal renewable water resource, if

348 lowest per capita (which is also business-as-usual) rate can be maintained by India, only $22 \%$

349 more renewable water resource will be needed in 2050. Otherwise, it would plunge to

$35072.15 \%$ if highest rate of renewable water resource per capita is to be maintained. 

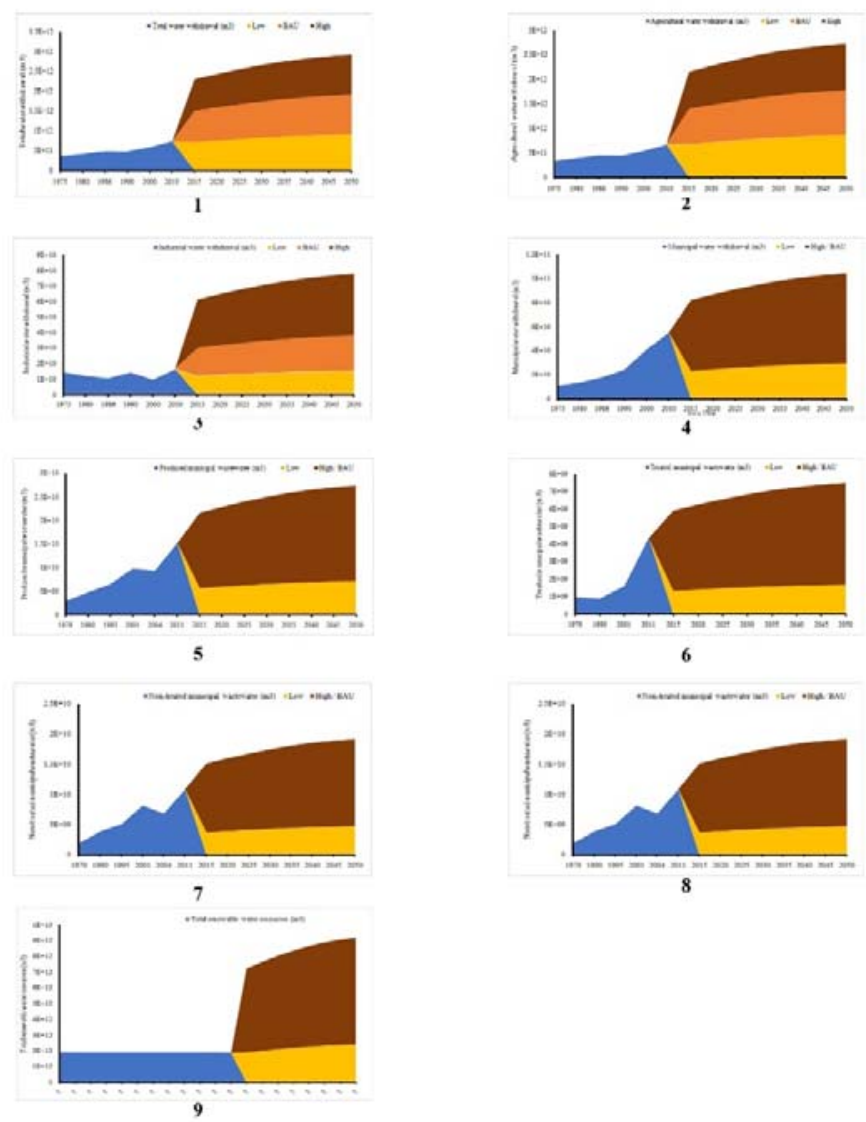

352

353 Fig. 3. Future scenario of indicators of biophysical consumption related to sustainable 354 development goal 6 for India up to 2050.

355 Blue indicates changes in total values of consumption. Brown indicates projected total values 356 at the highest rate of per capita consumption; Orange indicates projected total values at 357 business-as-usual (BAU) rate of per capita consumption, Yellow indicates projected total 358 values at a lowest rate of per capita consumption.

\section{Discussion:}

360 This study clearly shows that the per capita biophysical resources are decreasing over time.

361 This trend would continue further with respect to population explosion and growing 362 urbanisation trends in India. However, it also shows that social developments related to water 363 and sanitation are improving, clearly at the cost of environment. To provide positive social 
364 development and maintaining the same while the population is exploding will be tough to

365 handle for the government. Especially, if all of these developments come at the cost of further 366 degradation of the environment.

367 During this study, we confronted some problems along with their probable mitigation 368 strategies. First, availability of biophysical resource consumption data is not good enough. 369 For the same reason, we were unable to perform any statistical analysis. In future, analysis 370 and freely available data concerning biophysical consumption at state and district level should be prepared and maintained, both for general awareness and scientific research purposes. Second, long-term data are not available for most of the indicators which are necessary for more accurate projection of future trends. Third, neither state-level comprehensive data for most of the indicators are available, nor the district or any other lower unit level. This simply creates a homogeneous outline of resource consumption and access at national level. This is not enough to redesign policy framework or restructure governance in accordance with scientific findings. Though it is enough for preliminary studies, would not be enough in future, especially when adaptive policy needs to be implemented customized for the local context. Fourth, abundance and availability of data of different biophysical parameters are much more than different socioeconomic indicators. It shows a clear bias towards the maintenance of biophysical data. This is not suitable for contemporary research works and creates problem to assess sustainability for all three dimensions (i.e. environment, society and development). Fifth, the set of indicators for sustainable development of water and sanitation sector does not yield a very complete and comprehensive picture of SDG 6 in India, especially in view of the socioeconomic factors that exist within the country and the regional biophysical resource consumption that interact with them. Therefore, there is ample scope for adapting the indicators to better suit India's specific needs in terms of reflecting both regional and national scenario. To this end, additional indicators could be developed. 
389 Sixth, as this study only etches the surface of multi-indicator multilevel continuous

390 monitoring of SDG 6, it is not rigorous enough to map synergy and trade-off between SDG 6

391 and other sustainable development goals (Griggs et al. 2014, Nilsson et al. 2016). Seventh,

392 awareness and know-how about water resource management in India is only catalysed by the

393 government in broad scale. Thus, government, nongovernment organizations (NGOs) and the

394 public, together should take more proactive steps towards promotion and utilization of water

395 resources to achieve sustainable development goals in water and sanitation (i.e. SDG 6) in

396 India. Eighth, to control misutilization and overexploitation of water resources, especially in

397 urban areas, regulatory instruments, such as - water utilization taxes, water recycling taxes

398 etc. will remain a vital component of policies, as efforts to increase water efficiency and

399 reduce environmental and socioeconomic impacts are usually unsupportable against a

400 background of low cost availability. Ninth, if consumers do not purchase devices with

401 improved water use efficiency and environment characteristics (e.g. agricultural transport and

402 household appliances etc.), when such devices are available commercially, these products

403 should be supplemented by more direct government intervention and investment if

404 advancement toward sustainable development in water resources are to be made. Tenth, since

405 agriculture and household are two major water consuming sector in India, utilization of

406 recycled and treated wastewater should be advocated. Eleventh, since agricultural water

407 withdrawal is highest in India among all other sectors, increasing agricultural water use

408 efficiency should be the highest priority through drip irrigation, hydroponics, urban terrace

409 and rooftop agriculture, utilization of treated household wastewater in agriculture etc.

410 Water resources and its utilization are intimately connected to sustainable development. For

411 Indian societies to attain sustainable development in water and sanitation, much effort must

412 be devoted not only to discover sustainable ways to consume of water resources but also to

413 increase the water use efficiencies (WUE) of processes utilizing water resources. Also, 
414 correlated environmental concerns must be addressed, continuously monitored and any type 415 or degree of declination must be solved. This proposed research framework would progress 416 our current understanding and measurement of SDG 6. Through measurement and 417 identification of how, when, and why changes in biophysical aspects of water and sanitation 418 influence human socioeconomic conditions over both time and space and vice-versa, we can 419 more fully appropriate and anticipate the impact of the bidirectional nature of human-water 420 interactions. This understanding might also be used to monitor, update and refine the national 421 SDG 6 framework. This would arm natural resource planning authorities with a decision 422 support and policy management tool that more accurately reflects the trade-offs between 423 various components of the SDG 6. As a final note, to make India water secure and sustainable 424 in 2030, India must endeavour to increase its efforts to attain greater efficiency in utilization, 425 consumption of water for both biophysical and socioeconomic purposes.

\section{Acknowledgement:}

427 This study was supported by FRPDF scheme (2013-2017) of Presidency University, Kolkata.

428 We would like to thank Sk. Rohan Tanvir, The Institution of Engineers (India) for his kind 429 assistance during the preparation of diagrams. 
References:

Ait-Kadi, M., 2016. Water for Development and Development for Water: Realizing the

Bartram, J., Brocklehurst, C., Fisher, M. B., Luyendijk, R., Hossain, R., Wardlaw, T.,

Gordon, B., 2014. Global monitoring of water supply and sanitation: history, methods and

future challenges. Int. J. Environ. Res. Public Health, 11 (8), 8137-8165. doi:10.3390/ijerph1 10808137. of health. PLoS Med. 7 (11), 1-9. doi: 10.1371/journal.pmed.1000367.

Bartram, J., Lewis, K., Lenton, R., Wright, A., 2005. Focusing on improved water and sanitation for health. Lancet. 365, 810-812. doi:10.1016/S0140-6736(05)17991-4.

Bhaduri, A., Bogardi, J., Siddiqi, A., Voigt, H., Vörösmarty, C., Pahl-Wostl, C., Bunn, S.E., Shrivastava, P., Lawford, R., Foster, S., Kremer, H., Renaud, F.G., Bruns, A., Osuna, V.R., 2016. Achieving Sustainable Development Goals from a Water Perspective. Front. Environ. Sci. 4, 1-13. doi: 10.3389/fenvs.2016.00064.

Biswas, A.K., 1992. Sustainable water development: A global perspective. Water Int. 17, 68-80. doi: 10.1080/02508069208686128.

Biswas, A.K., 1991. Water for Sustainable Development in the 21st Century: A Global Perspective. Int. J. Water Resour. Dev. 7 (4), 219-224. doi: $10.1080 / 07900629108722516$.

Bogardi, J.J., Dudgeon, D., Lawford, R., Flinkerbusch, E., Meyn, A., Pahl-Wostl, C., Vielhauer, K., Vörösmarty, C., 2012. Water security for a planet under pressure: Interconnected challenges of a changing world call for sustainable solutions. Curr. Opin. 
464 Environ. Sustain. 4, 35-43. doi: 10.1016/j.cosust.2011.12.002.

465 Brundtland, G.H., 1987. Our Common Future. Oxford University Press, New York.

$466 \quad$ FAO $2018 . \quad$ Aquastat online database

467 http://www.fao.org/nr/water/aquastat/main/index.stm (accessed 28.04.2018)

468 FAO 2018. FAOSTAT online database; http://faostat.fao.org/ (accessed 28.04.2018)

$469 \quad$ IndiaStat 2018. https://www.indiastat.com/ (accessed 22.05.2018)

470 Gleick, P.H., 1996. Basic water requirements for human activities: Meeting basic needs.

$471 \quad$ Water Int. 21, 83-92, doi: 10.1080/02508069608686494.

472 Gleick, P.H., 1998. Water in crisis: paths to sustainable water use. Ecol. Appl. 8 (3), 571 -

473 579. doi: 10.1890/1051-0761(1998)008[0571:WICPTS]2.0.CO;2.

474 Griggs, D., Stafford-Smith, M., Gaffney, O., Nature, J.R.-, 2013. Policy: Sustainable

475 development goals for people and planet. Nature, 495, 305-307. doi: 10.1038/495305a.

476 Jackson, R.B., Carpenter, S.R., Dahm, C.N., McKnight, D.M., Naiman, R.J., Postel, S.L.,

477 Running, S.W., 2001. Water in a changing world. Ecol. Appl. 11 (4), 1027-1045. doi:

$478 \quad 10.1890 / 1051-0761(2001) 011[1027: W I A C W] 2.0 . C O ; 2$.

479 Kumar, R., Singh, R.D., Sharma, K.D., 2005. Water resources of India. Curr. Sci. 89 (5),

$480 \quad$ 794-811. doi: 10.1002/047147844X.wr243

481 Madrid, C., Cabello, V., Giampietro, M., 2013. Water-Use Sustainability in 482 Socioecological Systems: A Multiscale Integrated Approach. Bioscience. 63, 14-24. doi: $483 \quad$ 10.1525/bio.2013.63.1.6.

484 Mall, R.K., Gupta, A., Singh, R., Singh, R.S., Rathore, L.S., 2006. Water resources and 485 climate change: An Indian perspective. Curr. Sci. 90 (12), 1610-1626. doi: $486 \quad 10.1016 / \mathrm{S} 0143-8166(02) 00004-0$.

487 Moe, C.L., Rheingans, R.D., 2006. Global challenges in water, sanitation and health. J. $488 \quad$ Water Health. 4 (S1), 41-57. doi: 10.2166/wh.2005.039. 
Montgomery, M.A., Elimelech, M., 2007. Water And Sanitation in Developing Countries: Including Health in the Equation. Environ. Sci. Technol. 41, 17-24. doi: $10.1021 / \mathrm{es} 072435 \mathrm{t}$

Mujumdar, P.P., 2008. Implications of climate change for sustainable water resources management in India. Phys. Chem. Earth. 33, 354-358. doi: 10.1016/j.pce.2008.02.014.

Nilsson, M., Griggs, D., Visbeck, M., 2016. Policy: Map the interactions between Sustainable Development Goals. Nature, 534, 320-322. doi: 10.1038/534320a. river dynamics by dams and global biodiversity implications. Proc. Natl. Acad Sci. 104 (14), 5732-5737. doi: 10.1073/pnas.0609812104.

Postel, S.L., 2000. Water and world population growth. J. Am. Water Work. Assoc. 2 (4), 131-138. doi: 10.1002/j.1551-8833.2000.tb08927.x.

Raworth, K., 2012. A safe and just space for humanity - Can we just live within the doughnut. Oxfam Policy and Practice: Climate Change and Resilience. 8 (1), 1-26. doi: 10.1080/00420980120087081. century. Lancet Planet. Health. 1 (2), e48-e49. doi: 10.1016/S2542-5196(17)30028-1. economist. Random House Business, T.M., Scheffer, M., Folke, C., Schellnhuber, H.J., Nykvist, B., de Wit, C.A., Hughes, T., van der Leeuw, S., Rodhe, H., Sorlin, S., Snyder, P.K., Costanza, R., Svedin, U., Falkenmark, M., Karlberg, L., Corell, R.W., Fabry, V.J., Hansen, J., Walker, B., humanity. Nature, 461, 472-475. doi: 10.1038/461472a. 
514 Rockström, J., Steffen, W., Noone, K., Persson, Å., Chapin, F.S., Lambin, E., Lenton, 515 T.M., Scheffer, M., Folke, C., Schellnhuber, H.J., Nykvist, B., de Wit, C.A., Hughes, T., 516 van der Leeuw, S., Rodhe, H., Sörlin, S., Snyder, P.K., Costanza, R., Svedin, U., 517 Falkenmark, M., Karlberg, L., Corell, R.W., Fabry, V.J., Hansen, J., Walker, B., 518 Liverman, D., Richardson, K., Crutzen, P., Foley, J., 2009b. Planetary boundaries: 519 Exploring the safe operating space for humanity. Ecol. Soc. 14 (2), 32. doi: 10.5751/ES$520 \quad 03180-140232$

Sachs, D. J., 2012. From millennium development goals to sustainable development goals. Lancet, 379, 2206-2211. doi: 10.1016/S0140-6736(12)60685-0

Serageldin, I., 1995. Water resources management: A new policy for a sustainable future.

Water Int. 20, 15-21. doi: 10.1080/02508069508686440.

Steffen, W., Crutzen, P.J., McNeill, J.R., 2007. The Anthropocene: Are Humans Now

Overwhelming the Great Forces of Nature. AMBIO A J. Hum. Environ. 36 (8), 614-621. doi: 10.1579/0044-7447(2007)36[614:TAAHNO]2.0.CO;2.

Steffen, W., Persson, Å., Deutsch, L., Zalasiewicz, J., Williams, M., Richardson, K.,

From global change to planetary stewardship, AMBIO A J. Hum. Environ. 40 (7), 739761. doi: 10.1007/s13280-011-0185-x.

Steffen, W., Richardson, K., Rockstrom, J., Cornell, S.E., Fetzer, I., Bennett, E.M., Biggs,

R., Carpenter, S.R., de Vries, W., de Wit, C.A., Folke, C., Gerten, D., Heinke, J., Mace, 
539 sustainable development,

540 https://sustainabledevelopment.un.org/content/documents/7891Transforming\%20Our\%20

$541 \quad$ World. pdf. https://doi.org/10.1007/s13398-014-0173-7.2

542

United Nations, Department of Economic and Social Affairs, Population Division (2017).

$544 \quad$ World Population Prospects: The 2017 Revision.

545 United Nations, 2015. Transforming Our World: The 2030 Agenda for Sustainable

546 Development (A/RES/70/1).

547 United Nations World Population Prospects: The 2017 Revision, (Population Division,

548 Department of Economic and Social Affairs, United Nations, 2017).

549 van Koppen, B., Shah, T., 2006. Is India Ripe for Integrated Water Resources

$550 \quad$ Management? Econ Polit Wkly. 41 (31), 3413-3421.

551 Vorosmarty, C.J., Green, P., Salisbury, J., Lammers, R. B., 2000. Global Water

552 Resources: Vulnerability from Climate Change and Population Growth. Science, 289

553 (5477), 284-288. doi: 10.1126/science.289.5477.284.

554 Vörösmarty, C.J., McIntyre, P.B., Gessner, M.O., Dudgeon, D., Prusevich, A., Green, P.,

555 Glidden, S., Bunn, S.E., Sullivan, C.A., Liermann, C.R., Davies, P.M., 2010. Global

556 threats to human water security and river biodiversity. Nature, 467, 555-561. doi:

$557 \quad 10.1038 /$ nature09440.

558 World Bank 2018. World Development Indicators (World Bank);

559 http://data.worldbank.org/. (accessed 28.04.2018)

560

561

562 


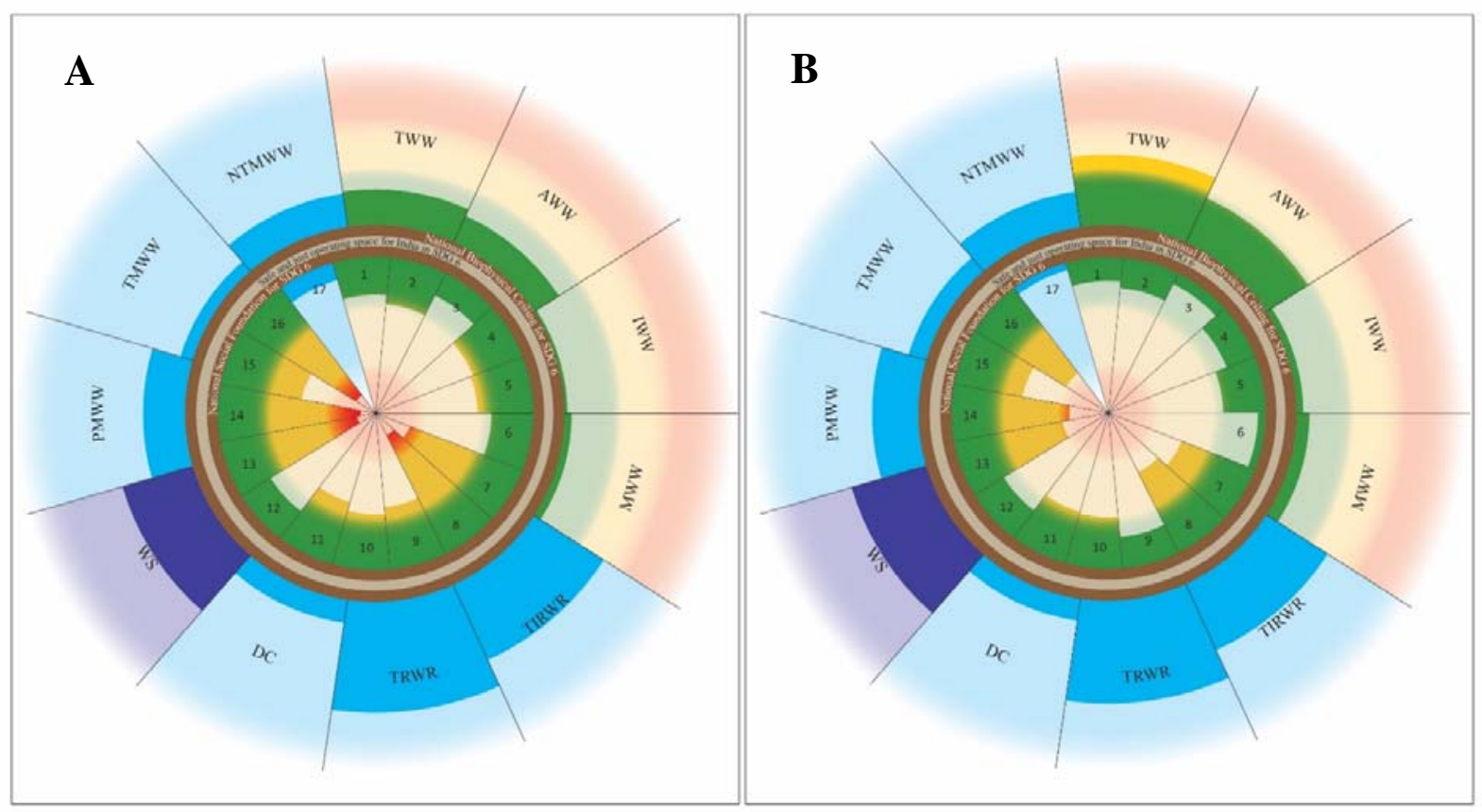

Fig. 1. Changes in biophysical and social development indicators related to sustainable development goal 6 in India.

A and B represent the status of sustainable development of India in 2000 and 2015 respectively. Eleven indicators of biophysical stress established over biophysical ceiling (outer chocolate ring) outwardly projected and seventeen indicators of social development established under social foundation (inner chocolate ring) inwardly projected for India. Biophysical indicators are - total water withdrawal (TWW), agricultural water withdrawal (AWW), industrial water withdrawal (IWW), municipal water withdrawal (MWW), total internal renewable water resource (TIRWR), total renewable water resource (TRWR), dam capacity (DC), water stress (WS), produced amount of municipal waste water (PMWW), treated municipal waste water (TMWW) and non-treated municipal waste water (NTMWW). Indicators of social development are - (1) Improved sanitation facilities, (2) Improved sanitation facilities in rural areas, (3) Improved sanitation facilities in urban areas, (4) Improved water source, (5) Improved water source in rural areas, (6) Improved water source in urban areas, (7) People practicing open defecation, (8) Rural people practicing open defecation, (9) Urban people practicing open defecation, (10) People using at least basic drinking water services, (11) Rural people using at least basic drinking water services, (12) Urban people using at least basic drinking water services, (13) People using at least basic sanitation services, (14) Rural people using at least basic sanitation services, (15) Urban people using at least basic sanitation services, (16) Rural people using safely managed drinking water services, (17) Water use efficiency in agriculture.

Green indicates safe operating space for biophysical indicators and thresholds for indicators of social development. Yellow indicates zone of increasing impact for biophysical indicators and zone of increasing deprivation for indicators of social development. Red indicates zone of high risk of serious impact for biophysical indicators and zone of high level of deprivation for indicators of social development. Light blue represents indicators without any boundary or thresholds (Unit - m3). Violet represents water stress (Unit - \%). Area between the chocolate rings is the safe and just operating space for sustainable development of water and sanitation in India. 

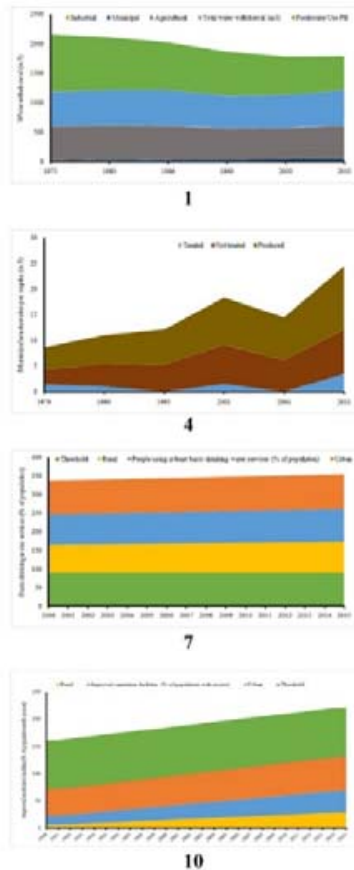
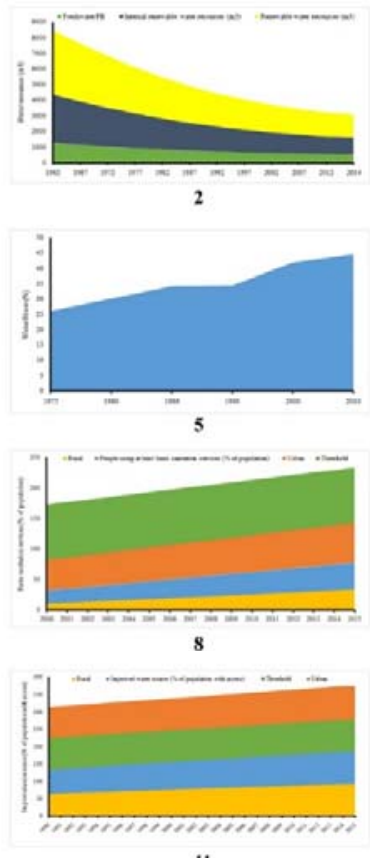
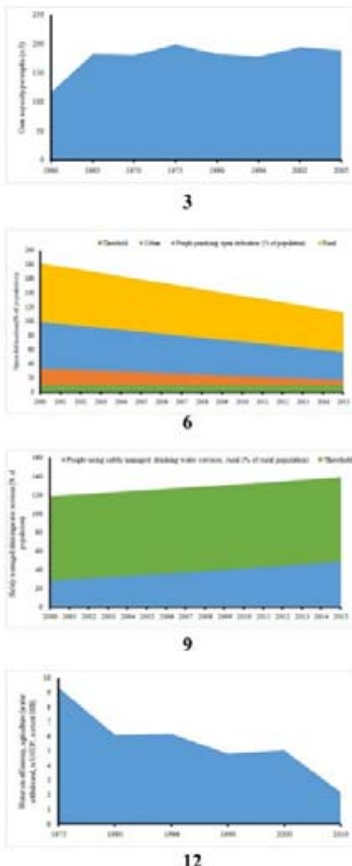

12

Fig. 2. Changes in per capita biophysical indicators (1-5) and indicators of social development (6-12) related to sustainable development goal 6 in India with time.

Green indicates global per capita boundaries for biophysical indicators and thresholds for indicators of social development.

Biophysical indicators are - (1) water withdrawal $\left(\mathrm{m}^{3}\right),(2)$ water resources $\left(\mathrm{m}^{3}\right),(3)$ dam capacity $\left(\mathrm{m}^{3}\right)$, (4) municipal wastewater $\left(\left(\mathrm{m}^{3}\right)\right.$ and (5) water stress $(\%)$. Indicators for social development are - (6) open defecation (\%), (7) basic drinking water services (\%), (8) basic sanitation services (\%), (9) safely managed drinking water services (\%), (10) improved sanitation facilities (\%) (11) improved water source $(\%)$ and $(12)$ water use efficiency in agriculture ( ${ }^{3} / \mathrm{GDP}$, current US\$). 

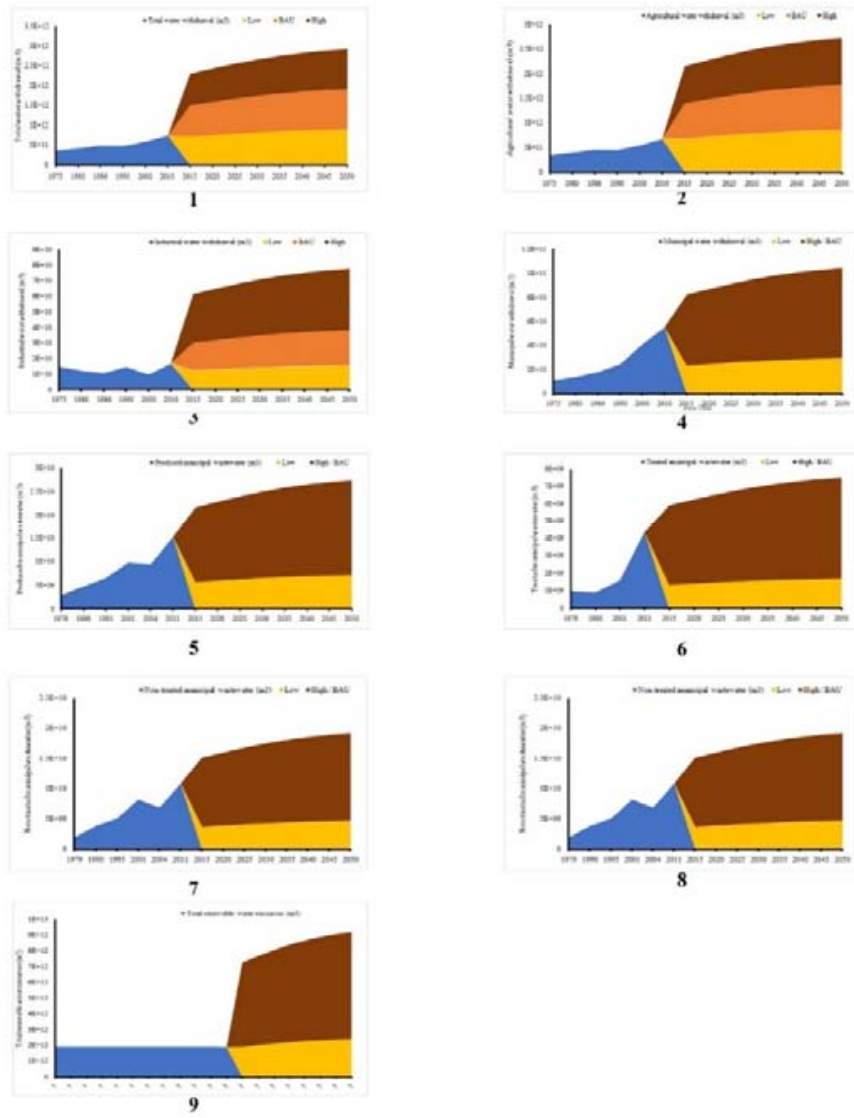

Fig. 3. Future scenario of indicators of biophysical consumption related to sustainable development goal 6 for India up to 2050.

Blue indicates changes in total values of consumption. Brown indicates projected total values at highest rate of per capita consumption; Orange indicates projected total values at business-as-usual (BAU) rate of per capita consumption, Yellow indicates projected total values at lowest rate of per capita consumption. 